Proc. Estonian Acad. Sci. Biol. Ecol., 2001, 50, 3, 200-210

\title{
ZOOPLANKTON STUDIES IN THE NEVA ESTUARY (BALTIC SEA): A BRIEF EXCURSION INTO HISTORY
}

\begin{abstract}
Irena V. TELESH
Zoological Institute of the Russian Academy of Sciences, Universitetskaya nab. 1, 199034 St. Petersburg, Russia; itelesh@zin.ru

Received 28 March 2001, in revised form 28 May 2001

Abstract. Zooplankton studies in the Neva estuary started in the early 20th century. During those pioneer investigations and in the following several decades mostly qualitative data were collected. Until the end of the 1970s, plankton research in the area was irregular and numerical data were scarce. In the 1980s zooplankton studies became an important part of comprehensive hydrobiological investigations aimed at evaluation of the functioning of the estuarine ecosystem. Recent studies have demonstrated the necessity to pay more attention to the problem of biological invasions of aquatic alien species to and from the ecosystem of the Neva estuary. At present this problem, together with the assessment of the response of zooplankton communities to anthropogenic stress, is among the major items of zooplankton research in the Neva estuary.
\end{abstract}

Key words: zooplankton, Neva estuary, history of research.

\section{INTRODUCTION}

The Neva estuary is the easternmost part of the Baltic Sea, one of its strongly eutrophicated sub-basins influenced by waste discharges from St. Petersburg and Leningradskaya Oblast. The upper part of the Neva estuary (Neva Bay) is a freshwater shallow semi-enclosed water system, which is connected with the outer estuary, the brackishwater eastern Gulf of Finland (EGF).* Zooplankton communities of the Neva estuary are characterized by high taxonomic diversity; moreover, they are of different structure in the upper and outer estuary. Numerically rotifers dominate the community in Neva Bay and copepods in the EGF (Telesh et al., 1999). For general information on the hydrobiological regime in the Neva estuary see Winberg \& Gutelmakher (1987). Background data on

* Editorial note: This paper does not follow the subdivision of the Neva estuary given in the previous paper (Panov et al., 2001, p. 194 and Fig. 1). 
depth, salinity, dissolved oxygen level, nutrient concentrations, and structure of sediments in the area can be found, for example, in Shiklomanov et al. (1989), Shishkin et al. (1989), Skakalski (1996), and Rybalko \& Fedorova (1996).

\section{EARLY STUDIES}

\section{First qualitative zooplankton data}

Zooplankton investigations in the Neva estuary have a history of almost a century. First zooplankton studies in this area were carried out at the beginning of the 20th century (1905-06) by an expedition of A. S. Skorikov to Lake Ladoga, the Neva River, Neva Bay, and adjacent waters of the Gulf of Finland. The expedition was arranged in the framework of a governmental programme aimed at improving the quality of the drinking water supply for the city of St. Petersburg. At that time, the aquatic fauna of the two last named regions was totally unknown, except for a few planktonic species mentioned in a paper about waters around Kronshtadt (Grimm, 1877). During two cruises around Neva Bay in September and October 1905, Skorikov's expedition collected 28 zooplankton samples at 10 sampling stations located along the sea channel and close to Kotlin. Results of those early studies allowed scientists to conclude that the plankton communities in Neva Bay, Neva River, and Lake Ladoga are similar though populations of several dominant species were found to be at different stages of development in these three basins (Skorikov, 1910).

During those pioneer studies as well as later, in the 1920s, description of the composition of the zooplankton community was one of the major scientific results. In 1911-12, according to the directive of the Municipal Executive Commission on the reconstruction of the water supply systems in St. Petersburg, hydrobiological investigations (mainly phytoplankton studies) were organized to characterize the degree of water pollution in different areas of Neva Bay. In the papers by Visloukh $(1913,1921)$ preliminary results of those studies were published. However, the author did not pay much attention to zooplankton and registered mainly common zooplankton species in the samples. As a result, the first list of zooplankton species for Neva Bay included only 45 species names. Later, Sokolova (1921) additionally indicated 18 rotifer species partly new for Neva Bay.

The structure and spatial distribution of the zooplankton community continued to be in the focus of hydrobiological studies in the Neva estuary during the following two decades when mostly qualitative data were collected, and quantitative information was very scarce. More detailed investigations of Neva Bay were carried out during the 1920s by researchers from the Hydrobiological Laboratory headed by K. M. Deryugin. Those studies resulted in the publication of a series of papers under a common title Investigations of the Neva River and Its Drainage Basin in 1922 through 1930, including a paper "Zooplankton of Neva Bay" by Rylov (1923). Analysis of the composition, origin, and distribution of zooplankton species and seasonal periodicity in their development was made by 
V. M. Rylov on qualitative basis. The zooplankton species list published by Rylov (1923) comprised 156 species. Those investigations were continued by M. F. Sokolova, who found 164 zooplankton species in the EGF and western Neva Bay; a major part of them were rotifers (Sokolova, 1927). Sokolova's results supported the conclusions on zooplankton origin and distribution in the area made earlier by Rylov (1923).

\section{First quantitative zooplankton studies}

First quantitative data on selected zooplankton species were obtained during the first regular biannual zooplankton sampling carried out by M. F. Sokolova at two permanent stations in the Neva estuary in 1935 through 1936 (Sokolova, 1949). Though the investigations revealed high diversity of zooplankton, the author did not describe it in many details. Only few zooplankton organisms such as Tintinnopsis and Vorticella (Protozoa), Synchaeta, Polyarthra, Keratella, and Notholca (Rotifera), and nauplii of Copepoda were subjected to numerical treatment. The general conclusion of this study stated only that, compared with phytoplankton, the zooplankton in the sea channel and in the waters close to Peterhof was less diverse, both in terms of species composition and numbers (Sokolova, 1949).

Nevertheless, information on zooplankton species composition, distribution, and development in the Neva estuary obtained and published by the researchers in the first half of the 20th century, though irregular and mainly qualitative, was of exceptional importance. It served as reference data for the purpose of further faunistic comparisons aimed at evaluation of long-term changes in the zooplankton communities and in biological diversity of the whole ecosystem of the Neva estuary.

\section{FROM IRREGULAR OBSERVATIONS TO MONITORING AND WATER QUALITY ASSESSMENT}

A new stage in zooplankton studies of the Neva estuary started in the late 1950s. Seasonal dynamics and vertical migrations of zooplankton in the EGF, and zooplankton as food for fish were studied mainly by scientists from the State Research Institute on Lake and River Fisheries (GosNIORHk) (Bityukov, 1958, 1961; Bityukov et al., 1971; Pidgaiko, 1971). General aspects of plankton distribution and biological seasons in the Baltic Sea were considered in numerous publications by Professor Nikolaev (1949, 1951, 1974; Nikolaev \& Krievs, 1962, and others).

In 1962-64, scientists from the Zoological Institute of the USSR Academy of Sciences conducted comprehensive investigations aimed at assessment of water pollution and self-purification in the Neva River and its tributaries. In the framework of these investigations, two main aspects were studied in respect to 
zooplankton: (1) factors influencing zooplankton community structure in the Neva River were analysed (Ivanova, 1968), and (2) the role of planktonic rotifers in water quality evaluation was estimated (Kutikova, 1968).

The irregularity of plankton studies prior to the end of the 1970s and scarcity of numerical data limited the usage of information from that period for comparative purposes. Since 1977, regular quantitative zooplankton sampling in the Neva estuary was started by the NW Administration for Hydrometeorology and Environmental Monitoring (SZUGKS). Results of these monitoring studies, published mainly as series of SZUGKS reports, provided valuable information on seasonal and inter-annual dynamics of common zooplankton species in the EGF (Basova, 1990, and others). Scientists from Leningrad State University contributed significantly to the knowledge of the distribution, seasonal dynamics, and vertical migrations of zooplankton in the EGF (Ryabova \& Sergeev, 1977; Sergeev \& Ryabova, 1981; Ryabova, 1984; Kryshev \& Ryabova, 1986; Ryabova \& Pogrebov, 1991).

The hydrobiological results obtained in the late 1970s were of great importance for future generations of aquatic ecologists because soon the construction of a dam for the protection of St. Petersburg from floods was started in the EGF. This significant human interference into the ecosystem has affected the ecological situation in the Neva estuary. In 1980, the ecological expertise of the region that had preceded the implementation of the project of storm-surge barrier construction in the Neva estuary was found to be insufficient (Shishkin et al., 1989). Therefore, since 1980 the State Hydrological Institute (GGI) was involved in the environmental monitoring and hydrobiological investigations in the EGF. During these studies, different biotic components were analysed, field and laboratory experiments were carried out, and the role of biota in water quality evaluation was estimated (Shishkin, 1987; Shishkin et al., 1989). Zooplankton of the EGF was studied from the viewpoint of species composition, spatial distribution, productivity, and water quality assessment (Silina, 1988, 1990, 1991).

\section{ZOOPLANKTON STUDIES AS PART OF COMPREHENSIVE ECOLOGICAL INVESTIGATIONS}

In 1982, the zooplankton studies in the Neva estuary became a special part of comprehensive hydrobiological investigations aimed at the evaluation of functional modes of the whole estuarine ecosystem, and a functional approach to zooplankton studies was applied (Telesh, 1987a). Since then, zooplankton diversity, abundance, spatial and vertical distribution, trophic structure, productivity and its peculiarities in the open and nearshore waters of the Neva estuary have been among the major items studied in this strongly polluted part of the Gulf of Finland (Telesh, 1986a, 1987b, 1988a, b; Pidgaiko, 1987; Khlebovich, 1987). Detailed taxonomic study of the zooplankton of Neva Bay conducted in 1982 through 1984 provided a list of 228 species: Infusoria-40, Rotifera-95, 
Cladocera-56, and Copepoda-37. The first extensive study of zooplankton among vast macrophyte associations in Neva Bay coupled with the use of finemesh nets and sedimentation method of sampling rotifers resulted in 57 new taxonomic records in the zooplankton community of this water body. The impact of inorganic turbidity and water flow velocity on the zooplankton community was measured in field and laboratory experiments (Telesh, 1986b, 1988c; Telesh et al., 1987; Pavelieva \& Kunina, 1987). The effect of hydrological factors (windinduced water flows and water temperature) on microzooplankton in the shallow coastal waters of the estuary was evaluated in a field experiment and a model was proposed to relate zooplankton concentration to water residence time in the littoral zone of Neva Bay (Preobrazhenskij et al., 1987). The role of zooplankton for fish feeding was estimated by Ogorodnikova \& Susloparova (1987).

\section{USE OF ZOOPLANKTON DATA FOR MODELLING AND ECOSYSTEM STATE EVALUATION}

In the 1990s, priority was given to comparative studies of the long-term hydrobiological data related to the progressing eutrophication in the Neva estuary (Alimov et al., 1994). The ecological role of rotifers, the major component of the zooplankton community in Neva Bay, was analysed from the aspect of the formation of rotifer assemblages, their relation to eutrophication, and perspectives of the estuary ecosystem (Telesh, 1995). In two basins of the Neva estuary shallow freshwater Neva Bay and deeper brackishwater EGF - response of aquatic communities to anthropogenic stress was compared (Telesh et al., 1999). Among other plankton studies, several attempts were made to assess the ecological state of Neva Bay and water flows in St. Petersburg on the basis of hydrobiological parameters, including zooplankton data (Ivanova \& Telesh, 1996; Alimov et al., 1998a); to evaluate water quality on the basis of knowledge of structural and functional characteristics of phyto- and zooplankton communities (Telesh \& Nikulina, 1997); and to estimate participation of zooplankton in the matter and energy flow in the EGF (Silina, 1997).

The International Finnish-Estonian-Russian research programme "Gulf of Finland Year 1996", which started in February 1994 and ended in March 1997, was an important phase in the history of zooplankton studies in the Neva estuary. It provided an excellent opportunity to summarize the existing knowledge on the structure and functioning of the Neva estuary ecosystem, with special reference to eutrophication, and compare it with other ecosystems of the Gulf of Finland. Thus, a scientific basis and guidelines for the pollution reduction measures in the area were created (Alimov et al., 1997; Leppänen et al., 1997; Sarkkula, 1997). This long-term data set along with knowledge about the functioning of various biotic components, including zooplankton, was finally used for the evaluation of the ecosystem's state and the modelling of Neva Bay (Umnov, 1996) and the EGF (Davidan \& Savchuk, 1997). 


\section{URGENT PROBLEMS AND PERSPECTIVES OF ZOOPLANKTON RESEARCH}

Results of long-term zooplankton studies have demonstrated the necessity of both basic ecological research and monitoring efforts in the Neva estuary (Telesh et al., 1999). Besides, there is evidence of urgent need to pay more attention to the problem of biological invasions of aquatic alien species to and from this region (Alimov et al., 1998b; Panov et al., 1999; Alimov et al., 2000). Among the recent invaders to the Neva estuary are Dreissena polymorpha Pallas (Bivalvia), Balanus improvisus Darwin (Cirripedia), Cordylophora caspia Pallas (Cnidaria), Gmelinoides fasciatus Stebb. (Amphipoda) (Orlova et al., 1999). One of the most recent planktonic aliens in the Neva estuary is the Ponto-Caspian predatory cladoceran Cercopagis pengoi Ostroumov (Crustacea: Onychopoda), which was first found in the EGF in 1995 (Panov et al., 1996). Since then, C. pengoi has formed a permanent population and become one of the common zooplankton species in the EGF. It is a model object for a number of detailed investigations, which have provided information on the morphology and structure of the population of C. pengoi (Krylov \& Panov, 1998; Litvinchuk \& Rivier, 1999; Litvinchuk et al., 2001), carbon content in the body of these crustaceans (Telesh et al., 1998), distribution and seasonal dynamics of the population (Avinski, 1997; Avinski \& Telesh, 1999; Krylov et al., 1999), the role of this alien species in the zooplankton community (Telesh et al., 2000) and in the diet of Baltic herring in the Neva estuary (Antsulevich \& Välipakka, 2000). Recently, predation pressure and overall impact of this predatory cladoceran on the zooplankton community in the EGF was measured (Telesh et al., 2001). Calculations show that a possible increase in the population density and, consequently, the growth of predation pressure of $C$. pengoi on planktonic filtrators in the estuary may result in an alteration of pelagic food webs. This is likely to be followed by changes of fluxes of matter and energy through the zooplankton community and the ecosystem in general, thus enhancing eutrophication of the Neva estuary.

Nowadays, the eutrophication processes have intensified not only in the Neva estuary but also in other Baltic coastal ecosystems such as the Vistula Lagoon, Curonian Lagoon, Darss-Zingst Boddens, etc. Comparative analyses of long-term changes in the plankton of these estuaries, evaluation of functional response of zooplankton communities to anthropogenic stress, and study of the autecology of alien species and the role of zooplankton in the regulation of water quality can be considered among the main goals for the future zooplankton research in these basins.

\section{CONCLUSIONS}

It is important to mention that gradual accumulation of scientific knowledge on zooplankton in the Neva estuary has been problem-oriented since the early 20th century. The ecosystem of the eastern Gulf of Finland has always been 
subjected to significant anthropogenic stress. For this reason, already the first zooplankton data in the area were collected in the framework of a governmental programme on drinking water quality evaluation. Since the last quarter of the 20th century, major zooplankton research and observations in the Neva estuary were made as part of comprehensive hydrobiological investigations. Those studies provided information for ecological modelling with prognostic purposes for the assessment of the ecosystem's state. At the present phase, it is essential to use the vast knowledge accumulated on the ecology of zooplankton communities in the Neva estuary for the ecosystem management aimed at improving the water quality and conservation of natural biological diversity in the Baltic coastal ecosystems.

\section{ACKNOWLEDGEMENTS}

The author gratefully acknowledges financial support of the Organizing Committee of the Symposium "History of Marine and Freshwater Research in Estonia and Neighbouring Countries" (1-2 February 2001, Tallinn, Estonia), which gave me the opportunity to participate in this symposium. I thank Piotr Krylov and the anonymous reviewer for valuable comments on the manuscript. The work was funded by the Russian Foundation for Basic Research (grants 99-04-49614, 00-15-97825, 01-04-49560), Maj and Tør Nessling Foundation, and INTAS (grant 99-06674).

\section{REFERENCES}

Alimov, A. F., Nikulina, V. N., Panov, V. E., Telesh, I. V. \& Finogenova, N. P. 1994. Hydrobiology of Neva Bay of the Gulf of Finland. Hydrobiol. J., 30 (4), 14-26.

Alimov, A. F., Telesh, I. V., Välipakka, P., Martin, G. \& Viitasalo, I. 1997. Biological state of the coastal waters of the Gulf of Finland - Report of the Working Group "Biological State and Changes". In Proceedings of the Final Seminar of the Gulf of Finland Year 1996, March 17-18, 1997 (Sarkkula, J., ed.), pp. 161-166. Suomen Ymparistokeskus, Helsinki.

Alimov, A. F., Panov, V. E., Balushkina, E. V., Golubkov, S. M., Nikulina, V. N., Telesh, I. V., Finogenova, N. P. \& Umnova, L. P. 1998a. Evaluation of the ecological state of the Neva Bay and the eastern Gulf of Finland using hydrobiological parameters. In Ecological Situation in St. Petersburg and Leningrad Region in 1997. Informational-Analytical Review (Frolov, A. K., ed.), pp. 109-119. Lencomecology, St. Petersburg (in Russian).

Alimov, A. F., Panov, V. E., Krylov, P. I., Telesh, I. V., Bychenkov, D. E., Zimin, V. L., Maksimov, A. A. \& Filatova, L. A. 1998b. The problem of anthropogenic introduction of non-native organisms into the water bodies of the Gulf of Finland drainage area. In Ecological Situation in St. Petersburg and Leningrad Region in 1997. InformationalAnalytical Review (Frolov, A. K., ed.), pp. 243-248. Lencomecology, St. Petersburg (in Russian).

Alimov, A. F., Orlova, M. I. \& Panov, V. E. 2000. The consequences of the introduction of the alien species for the water ecosystems and the necessity of the arrangements for their avoidance. In Species Introducers in the European Seas in Russia, pp. 12-23. Apatity (in Russian). 
Antsulevich, A. \& Välipakka, P. 2000. Cercopagis pengoi - new important food object of the Baltic herring in the Gulf of Finland. Int. Rev. Hydrobiol., 85 (5-6), 609-619.

Avinski, V. A. 1997. Cercopagis pengoi - a new species in the eastern Gulf of Finland ecosystem. In Proceedings of the Final Seminar of the Gulf of Finland Year 1996, March 17-18, 1997 (Sarkkula, J., ed.), pp. 247-256. Suomen Ymparistokeskus, Helsinki.

Avinski, V. A. \& Telesh, I. V. 1999. Composition and numerical characteristics of zooplankton. In The Gulf of Finland in the Conditions of Anthropogenic Stress (Rumyantsev, V. A. \& Drabkova, V. G., eds.), pp. 161-189. St. Petersburg (in Russian).

Basova, S. L. (ed.) 1990. Annual Report on the Quality of Sea Waters in the Eastern Gulf of Finland Based on Hydrobiological Parameters in 1989. Leningrad (in Russian).

Bityukov, E. P. 1958. On the problem of diurnal migration of planktonic crustaceans in the Gulf of Finland. Nauchno-techn. bull. VNIORH, 6-7, 63-67 (in Russian).

Bityukov, E. P. 1961. Nutrition of the Baltic herring (Clupea harengus membras L.) in the eastern part of the Gulf of Finland. Vopr. ikhtiol., 1, 4 (21), 725-736 (in Russian).

Bityukov, E. P., Greze, V. N. \& Petrovskaya, M. V. 1971. Zooplankton of the Gulf of Finland. Izv. GosNIORH, 76, 46-64 (in Russian).

Davidan, I. N. \& Savchuk, O. P. (eds.) 1997. International Project "Baltica”, Issue 5. Ecosystem Models. Assessment of the Modern State of the Gulf of Finland. Gidrometeoizdat, St. Petersburg (in Russian).

Grimm, O. A. 1877. On the knowledge of fauna of the Baltic Sea and history of its origin. $T r$. St.-Peterb. Obshch. Estestvoispyt., 8, 107-138 (in Russian).

Ivanova, M. B. 1968. Plankton Crustacea of the Neva river and its tributaries. Proc. Zool. Inst. USSR Acad. Sci., 45, 202-210. Nauka, Leningrad (in Russian).

Ivanova, M. B. \& Telesh, I. V. 1996. Evaluation of the ecological state of the Neva Bay and water flows in St. Petersburg on the basis of zooplankton. In Ecological State of Water Bodies and Flows in the Neva River Drainage Basin (Alimov, A. F. \& Frolov, A. K., eds.), pp. 36-52. Scientific Centre RAS, St. Petersburg (in Russian).

Khlebovich, T. V. 1987. Planktonic Infusoria. In Neva Bay: Hydrobiological Investigations (Winberg, G. G. \& Gutelmakher, B. L., eds.), pp. 77-82. Nauka, Leningrad (in Russian).

Krylov, P. I. \& Panov, V. E. 1998. Resting eggs in the life cycle of Cercopagis pengoi, a recent invader of the Baltic Sea. Arch. Hydrobiol. Spec. Issues Advanc. Limnol., 52, 383-392.

Krylov, P. I., Bychenkov, D. E., Panov, V. E., Rodionova, N. V. \& Telesh, I. V. 1999. Distribution and seasonal dynamics of the Ponto-Caspian invader Cercopagis pengoi (Crustacea, Cladocera) in the Neva Estuary (Gulf of Finland). Hydrobiologia, 393, 227-232.

Kryshev, I. I. \& Ryabova, V. N. 1986. Periodical processes in the zooplankton dynamics in the eastern Gulf of Finland. Proc. Zool. Inst. USSR Acad. Sci., 141, 43-57 (in Russian).

Kutikova, L. A. 1968. The use of Rotatoria in biological estimation of Neva water. Proc. Zool. Inst. USSR Acad. Sci., 45, 193-201.

Leppänen, J.-M., Pitkänen, H., Savchuk, O., Basova, S., Drabkova, V., Gran, V., Heiskanen, A.-S., Koponen, J., Shpaer, I. \& Silina, N. 1997. Eutrophication and its effects in the Gulf of Finland. In Proceedings of the Final Seminar of the Gulf of Finland Year 1996, March 17-18, 1997 (Sarkkula, J., ed.), pp. 31-49. Suomen Ymparistokeskus, Helsinki.

Litvinchuk, L. F. \& Rivier, I. K. 1999. Structure of population and seasonal variability of morphological features in Cercopagis pengoi (Crustacea, Branchiopoda, Onychopoda) in the Gulf of Finland. In Problems of Ecology and Biodiversity of Aquatic and Near-Shore Ecosystems, pp. 56-58. Borok (in Russian).

Litvinchuk, L. F., Rivier, I. K. \& Panov, V. E. 2001. Dynamics of abundance, structure of population and fecundity of Ponto-Caspian predaceous cladoceran, Cercopagis pengoi (Ostroumov, 1891) (Polyphemoidea, Cercopagidae), in the Eastern Gulf of Finland, the Baltic Sea. Biol. Inland Waters, 1, 57-62 (in Russian).

Nikolaev, I. I. 1949. On the expansion of the warm-water and salt-water elements of flora and fauna to the inner (eastern) Baltic. Dokl. Acad. Sci. USSR, 68 (2), 397-400 (in Russian). 
Nikolaev, I. I. 1951. On the new aliens in the fauna and flora of the North Sea and the Baltic from the remote regions. Zool. zh., 30 (6), 556-561 (in Russian).

Nikolaev, I. I. 1974. Main tendencies in biology of the contemporary Baltic. Okeanologia, 14 (6), 1059-1069 (in Russian).

Nikolaev, I. I. \& Krievs, H. K. 1962. Numerical characteristics of zooplankton of the central Baltic. Tr. BaltNIRO, 8, 88-96 (in Russian).

Ogorodnikova, V. A. \& Susloparova, O. M. 1987. Feeding of the common species of fish. In Neva Bay: Hydrobiological Investigations (Winberg, G. G. \& Gutelmakher, B. L., eds.), pp. 174 181. Nauka, Leningrad (in Russian).

Orlova, M. I., Panov, V. E., Krylov, P. I., Telesh, I. V. \& Khlebovich, V. V. 1999. Changes in planktonic and benthic communities of the eastern part of the Gulf of Finland concerned with bio-invasions. Proc. Zool. Inst. RAS, 279, 305-325 (in Russian).

Panov, V. E., Krylov, P. I. \& Telesh, I. V. 1996. The Caspian predatory cladoceran Cercopagis pengoi invades the Gulf of Finland. BFU Res. Bull., 2, 80-81.

Panov, V. E., Krylov, P. I. \& Telesh, I. V. 1999. The St. Petersburg harbor profile. In Initial Risk Assessment of Alien Species in Nordic Coastal Waters (Gollasch, S. \& Leppäkoski, E., eds.), Nord 1999: 8, pp. 225-244. Nordic Council of Ministers, Copenhagen.

Pavelieva, E. B. \& Kunina, T. A. 1987. Influence of turbidity on self-purification of Neva Bay. In Neva Bay: Hydrobiological Investigations (Winberg, G. G. \& Gutelmakher, B. L., eds.), pp. 52-55. Nauka, Leningrad.

Pidgaiko, M. L. 1971. Zooplankton of the eastern Gulf of Finland as food for the sprat. Izv. GosNIORH, 76, 65-74 (in Russian).

Pidgaiko, M. L. 1987. Net-sampled zooplankton in the open part of the Neva Bay in 1981-1982. In Neva Bay: Hydrobiological Investigations (Winberg, G. G. \& Gutelmakher, B. L., eds.), pp. 103-105. Nauka, Leningrad (in Russian).

Preobrazhenskij, L. Yu., Telesh, I. V. \& Khlebovich, T. V. 1987. Influence of hydrological factors on the formation of littoral zooplankton communities. In Neva Bay: Hydrobiological Investigations (Winberg, G. G. \& Gutelmakher, B. L., eds.), pp. 105-111. Nauka, Leningrad (in Russian).

Ryabova, V. N. 1984. Distribution of zooplankton in the eastern Gulf of Finland. Vestn. LGU, 9 (2), 12-20 (in Russian).

Ryabova, V. N. \& Sergeev, V. N. 1977. Peculiarities of diurnal vertical migrations of zooplankton in the eastern Gulf of Finland. Izv. GosNIORH, 123, 65-77 (in Russian).

Ryabova, V. N. \& Pogrebov, V. B. 1991. Biological seasonality in the zooplankton of the Gulf of Finland. Gidrobiol. zh., 27 (1), 19-24 (in Russian).

Rybalko, A. E. \& Fedorova, N. K. 1996. Bottom sediments and geochemical processes at the sediment-water interface in the system: southern Lake Ladoga-Neva River-Neva Estuary. In Ecological State of Water Bodies and Water Flows of the Neva River Drainage Basin (Alimov, A. F. \& Frolov, A. K., eds.), pp. 68-90. Scientific Centre RAS, St. Petersburg (in Russian).

Rylov, V. M. 1923. Zooplankton of the Neva Bay. In Investigations of the Neva River and Its Drainage Basin, pp. 1-85. Petrograd (in Russian).

Sarkkula, J. (ed.) 1997. Proceedings of the Final Seminar of the Gulf of Finland Year 1996, March 17-18, 1997. Suomen Ymparistokeskus, Helsinki.

Sergeev, V. N. \& Ryabova, V. N. 1981. Analysis of seasonal succession of zooplankton in the eastern Gulf of Finland. Ecologiya, 3, 78-85 (in Russian).

Shiklomanov, I. A., Preobrazhenskij, L. Yu., Skakalski, B. G. \& Shishkin, B. A. 1989. Hydrological and ecological studies in water system: Lake Ladoga-Neva River-Neva Bay. Izv. VNIIG, 213, 14-29 (in Russian).

Shishkin, B. A. 1987. Dynamics of the processes of synthesis and decomposition of organic matter. In Neva Bay: Hydrobiological Investigations (Winberg, G. G. \& Gutelmakher, B. L., eds.), pp. 55-65. Nauka, Leningrad (in Russian). 
Shishkin, B. A., Nikulina, V. N., Maksimov, A. A. \& Silina, N. I. 1989. Main Characteristics of the Biota of the Gulf of Finland and Its Role in the Formation of Water Quality. Gidrometeoizdat, Leningrad (in Russian).

Silina, N. I. 1988. Planktonic Infusoria of the eastern part of the Gulf of Finland and their role in destruction of organic matter. In Hydrobiological Investigations of the Sea and Fresh Waters, pp. 25-29. Zoological Inst. USSR Acad. Sci., Leningrad (in Russian).

Silina, N. I. 1990. Rotifers of the eastern Gulf of Finland. In Rotifers (Kutikova, L. A., ed.), pp. 6569. Zoological Inst. USSR Acad. Sci., Leningrad (in Russian).

Silina, N. I. 1991. Modern state of zooplankton of the eastern Gulf of Finland, Baltic Sea. Okeanologiya, 31 (4), 616-620 (in Russian).

Silina, N. I. 1997. Zooplankton and its participation in the biotic turnover. In International Project "Baltica", Issue 5: Ecosystem Models. Assessment of the Modern State of the Gulf of Finland. Part II (Davidan, I. N. \& Savchuk, O. P., eds.), pp. 390-404. Gidrometeoizdat, St. Petersburg (in Russian).

Skakalski, B. G. 1996. Assessment of Lake Ladoga effect on the discharge of the dissolved chemical substances into the Gulf of Finland. Publ. Karelian Inst., Univ. Joensuu, 112, $148-152$.

Skorikov, A. S. 1910. On the fauna of Neva Bay and waters adjacent to island Kotlin. Zool. Museum Acad. Sci. Ann. Rep., 15, 474-489 (in Russian).

Sokolova, M. F. 1921. On the fauna of rotifers from the surroundings of Stary Petergof. Tr. Petrogr. Soc. Naturalists, 52 (1), 127-139 (in Russian).

Sokolova, M. F. 1927. Zooplankton of the eastern Gulf of Finland. In Studies of the River Neva and Its Drainage Basin, pp. 173-180. Leningrad (in Russian).

Sokolova, M. F. 1949. Numerical data on the plankton of the open waters and the near-shore area of the Neva Bay. Sci. Rep. Leningrad Univ., Ser. Biol., 21 (126), 67-106 (in Russian).

Telesh, I. V. 1986a. Transformation of the lake zooplankton in rivers. Dokl. USSR Acad. Sci., 291, 495-498 (in Russian).

Telesh, I. V. 1986b. Modern state of the zooplankton community in the Neva Bay. Tr. GosNIORH, 248, 142-149 (in Russian).

Telesh, I. V. 1987a. Present-day knowledge on the zooplankton of the Neva Bay. In Neva Bay: Hydrobiological Investigations (Winberg, G. G. \& Gutelmakher, B. L., eds.), pp. 75-77. Nauka, Leningrad (in Russian).

Telesh, I. V. 1987b. Planktonic rotifers and crustaceans. In Neva Bay: Hydrobiological Investigations (Winberg, G. G. \& Gutelmakher, B. L., eds.), pp. 82-103. Nauka, Leningrad (in Russian).

Telesh, I. V. 1988a. The role of mineral seston in determining the zooplankton community structure. In Hydrobiological Investigations of the Sea and Fresh Waters, pp. 44-47. Zoological Inst. USSR Acad. Sci., Leningrad (in Russian).

Telesh, I. V. 1988b. Composition and abundance of zooplankton in the macrophyte associations. Proc. Zool. Inst. USSR Acad. Sci., 186, 17-20 (in Russian).

Telesh, I. V. 1988c. Dynamics of population density and production of planktonic crustaceans. Proc. Zool. Inst. USSR Acad. Sci., 186, 37-47 (in Russian).

Telesh, I. V. 1995. Rotifer assemblages in the Neva Bay, Russia: Principles of formation, present state and perspectives. Hydrobiologia, 313/314, 57-62.

Telesh, I. V., Pavelieva, E. B. \& Chernova, G. B. 1987. Modern view on the formation of potamoplankton. Proc. Zool. Inst. USSR Acad. Sci., 172, 154-166 (in Russian).

Telesh, I. V. \& Nikulina, V. N. 1997. Water quality classification based on plankton communities. In Proceedings of the Final Seminar of the Gulf of Finland Year 1996, March 17-18, 1997 (Sarkkula, J., ed.), pp. 167-175. Suomen Ymparistokeskus, Helsinki.

Telesh, I. V., Panov, V. E. \& Viljanen, M. 1998. Carbon content of Cercopagis pengoi Ostroumov (Crustacea, Cladocera), the recent invader to the Gulf of Finland, the Baltic Sea. In XXVII SIL Congress, Aug. 8-14, 1998, Dublin (Ireland), Book of Abstracts, p. 347. 
Telesh, I. V., Alimov, A. F., Golubkov, S. M., Nikulina, V. N. \& Panov, V. E. 1999. Response of aquatic communities to anthropogenic stress: A comparative study of Neva Bay and the eastern Gulf of Finland. Hydrobiologia, 393, 95-105.

Telesh, I. V., Litvinchuk, L. F., Bolshagin, P. V., Krylov, P. I. \& Panov, V. E. 2000. Peculiarities of biology of the Ponto-Caspian species Cercopagis pengoi (Crustacea: Onychopoda) in the Baltic Sea. In Species Introducers in the European Seas in Russia, pp. 130-151. Apatity (in Russian).

Telesh, I. V., Bolshagin, P. V. \& Panov, V. E. 2001. Quantitative estimation of the impact of alien species Cercopagis pengoi (Crustacea: Onychopoda) on the structure and functioning of plankton community in the Gulf of Finland, Baltic Sea. Dokl. Biol. Sci., 377, 157-159.

Umnov, A. A. 1996. Use of mathematical models for the ecological state evaluation of water bodies (case study of the Neva Bay). In Ecological State of Water Bodies and Flows in the Neva River Drainage Basin (Alimov, A. F. \& Frolov, A. K., eds.), pp. 155-186. Scientific Centre RAS, St. Petersburg (in Russian).

Visloukh, S. M. 1913. Brief report on biological studies of the Neva Bay in 1911-1912. In Materials on the Investigation of the Neva Bay, pp. 215-312. St. Petersburg (in Russian).

Visloukh, S. M. 1921. On the knowledge on micro-organisms in the Neva Bay. Proc. Russ. Hydrol. Inst., 1-3, 83-96 (in Russian).

Winberg, G. G. \& Gutelmakher, B. L. (eds.) 1987. Neva Bay: Hydrobiological Investigations. Nauka, Leningrad (in Russian).

\section{ZOOPLANKTONI UURINGUD NEEVA JÕE SUUDMES: LÜHIKE EKSKURSIOON MINEVIKKU}

\section{Irena V. TELESH}

Zooplanktoni uuringuid Neeva jõe suudmes alustati 20. sajandi alguses. Mitmete aastakümnete vältel piirdusid need peamiselt kvalitatiivsete andmete kogumisega. Kuni 1970. aastateni olid uuringud ebaregulaarsed ja kogutud andmebaas tagasihoidlik. 1980. aastatel sai zooplankton piirkonna ulatuslike, estuaari ökosüsteemi funktsioneerimist selgitavate hüdrobioloogiliste uuringute oluliseks osaks. Hiljuti saadud tulemused kinnitavad tarvidust pöörata suuremat tähelepanu bioloogilise invasiooni probleemistikule, seda nii estuaari sisse kui ka sealt välja suunatuse aspektist. Nüüdisajal on viimati mainitud teema koos planktonikooslustes antropogeense stressi tõttu toimuvate muutuste hindamisega esikohal Neeva jõe suudme zooplanktoni uuringutes. 